\title{
Econometric Analysis of Farmers Access to Agricultural Credit and Repayment in South East, Nigeria: Implications for Poverty Alleviation
}

\author{
Ugbajah M. 0. \\ Department of Agricultural Economics and Extension \\ Chukwuemeka Odumegwu Ojukwu University, Igbariam \\ J. T. Amah \\ Department of Agricultural Economics and Extension \\ Chukwuemeka Odumegwu Ojukwu University, Igbariam
}

\begin{abstract}
The study analysed farmers access to agricultural credit and repayment in Southeast, Nigeria. The study specifically described the socioeconomic characteristics of the respondents, sources of credit awareness, and effects of socioeconomic characteristics on use and repayment of credit. Multistage and simple random sampling methods were used to select 120 respondents. Primary data were collected by means of questionnaire and 3 point likert scale. Non parametric and parametric statistical tools including frequency, distribution, percentages, mean ranking and multiple regression were deployed for data analyses majority (72\%) of the respondents were married, $75 \%$ had above 11 years experience in farming, mean credit obtained was $\mathrm{N108,866.7}$ and mean amount repaid $N$ 6405.2. the output of the multiple regression $R^{2}$ of $83 \%$ with the coefficient of education, farming experience, credit awareness and interest rate were significant of the 0.05 probability level. The farmer's access to agricultural credit should be ensured by provision of interest free credit facilities, minimizing beaucratic bottlenecks, education of farmers in proper utilization of credit and training on management and saving mobilization should be encouraged.
\end{abstract}

Keywords: Rural farmers, Mobilization, Income, Access, Utilization and Management

\section{INTRODUCTION}

Agriculture is the main stay in the country's economy, and contributes to the productivity employment incomes and good living standard (Amah, 2011). The renewed focus on agriculture as building the key to national development in the face of an uncertain and vulnerable oil economy poses a compelling challenge to the rural farmer's access to credit delivery and utilization (Nenna, Ugbajah and Ugwumba 2012). Nigeria is the most resource endowed nations in the world but socio-economically, Nigeria are among the poor in the world (Ebo, 2011). Unfortunately small-scale farmers in sub-Saharan Africa are characterized by poverty. This poverty affects their investment in agriculture. The agricultural sector including crops, livestock, fisheries and forestry sub-sectors is central to the economic activities in Nigeria and has accounted for 31 to 42 percent of gross Domestic product (G.D.P) between 2005 and 2008. In addition it provides paid and self employment to over 70 percent of the population (central Bank of Nigeria (C.B.N) 2007, fresh plaza, 2008). The need to maintain sustainable agricultural production and order to achieve overall economic development cannot be overemphasized. Before now both federal and state government have through several programmes perused rural and agricultural development in Nigeria, the rural being always the target of such programmes (C B N, 2005). CBN noted that rural farmers should be the centre 
piece of increased agricultural production (CBN, 2007). The impact of rural farmers in agricultural and economic development cannot be overemphasized. Many studies acknowledged this (Okpukpara, 2005, and Adeleye 2008). Government encourage local growers through programmes and projects which include Nigeria Agricultural cooperative and rural development Bank (NACRDB), Agricultural credit guarantee scheme fund (ACGSF), National agriculture insurance company (ADP), River Basin Development Authorities (RBDA), Special programme on food security (SPFS), community based natural resources management programme, Niger Delta south-south co-operation initiative, National economic empowerment development strategy (NEFDS), fada 1 and 11 projects, Root and tuber expansion projects (RTEP), presidential initiatives on cassava, rice, vegetable oils, tree crops, livestock, fishery and Aquaculture. The agricultural credit support scheme (ACSS) was established in 2006 for financing large agricultural projects such as management of plantations, cultivation or production of crops, livestock, and fisheries and farm machinery and hire services. The borrowing rate is $14 \%$ with the central bank of Nigeria (CBN), absorbing six percent while the borrower pays eight percent at full repayment in 2008. Large scale agriculture credit was established by the federal government in the wake of the current global economic crisis to finance large integrated commercial farm projects with an asset base of N350 million excluding land and medium sized agricultural enterprises with an asset base of N200 million (CBN, 2007). The impact of rural farmers in agriculture and economic development cannot be overemphasized. Many studies acknowledged this (Okpukpara 2005 and Adeleye, 2008). However, rural farmers are faced with different constraints in the quest to meet food production target. Many researchers have conclusively acknowledged that access to credit in the rural areas is a major constraint militating against farmer's agricultural production (Idachaba, 2006 and Anambra State Government 2008). The need to maintain sustainable agriculture and rural development in the current initiative, credit programmes has thus far been extremely limited in Nigeria rural setting. In this current system of global economic innovative development efforts should be targeted towards financial challenges with regard to rural transformation. The major problem associated with rural farmers agricultural production is that income generation and expenditure do not occur at the same because the type of production in which the rural farmers engage in is always seasonal. In spite of the strategies to increase access to formal financial services in rural areas the problem still persists (CBN, 2005 and Afolabi, 2008). It is therefore against the backdrop that this study was designed to examine the strategies for necessary rural farmer's access to agriculture credit and constraints in south east, Nigeria

\section{OBJECTIVES OF THE STUDY}

The overall objective of the study was to conduct an econometric analysis of farmer's access to agricultural credit and repayment in south east, Nigeria. The specific objectives were;

1. Examine the socio-economic characteristics of the respondents

2. Identify sources of credit

3. Examine effects of socioeconomic characteristics on credit use, repayments and identify constraints to credit access and also use the result of the study to make recommendations to improve famer's access to agricultural credit facilities.

\section{METHODOLOGY}

The study was conducted in the rural setting of Southeast, Nigeria. The area is located between latitudes $4^{0}$ and $14^{0} \mathrm{~N}$ and longitudes $3^{0}$ and $14^{0} \mathrm{E}$, covering a land area of about $924,000 \mathrm{~km}^{2}$ with a population of the country as released recently showed that Nigeria has a population of over 140million (NPC, 2007). The study was carried out in the Southeast geographical zone of the country. This is made up of five states out of the 36 states of the Federal Republic of Nigeria. The five Southeastern states are: Abia, Anambra, Ebonyi Enugu and Imo. The area had 
a total population of 25.9 million, which is about $30 \%$ of the population of the country (NPC, 1991). The southeast lies in the core oil palm belt of Nigeria, is among the most densely settled area of the country with an average population density of 247 persons per square kilometer as against the national average of 96 persons per square kilometer (NPC, 1991).

During the rainy season, a marked interruption in the rains occurs during August, resulting in a short dry season often referred to as the "August break", though for years now this has not been consistent in August due to climate change. Temperatures are slightly lower in the humid tropical region of the south east when compared with northern Nigeria. Similarly, humidity is lowered in December and January during the Harmattan or dry season when cool dry winds blow off the desert (Okonkwo and Mbajiorgi). Seventy percent is arable land which is under cultivation. The area is situated on a fairly flat land with tropical vegetation. It has a weak soil that is easily eroded, thus accounting for over 500 erosion sites of varying depths and length (SEEDS, 2006). Agriculture is the predominant occupation in the rural areas of the zone engaging more than $70 \%$ of the rural population. The major crops cultivated in the state are cassava, yam, rice, maize, cocoyam, oil palm, plantain//banana, beans and leafy vegetables. The farming system is root crop - based and characterized by inter - crops. The choice of the area was based on the intense economic activities including agriculture. Also there is a high degree of socio - cultural homogeneity in the study area as the inhabitants are mainly Igbos, known mainly for their hard work, self - reliance and ecomic prowess. An important feature of the farming system in the upland areas, where there is pressure on land, is compound and homestead farms. Compound farms integrate not only arable crops and tree crops but also livestock and at times fisheries (Ugbajah, 2011). The dominant criterion for selecting southeast is the prevalence of formal and informal financial institutions in most of the rural areas of the zone.

Multistage and simple random sampling technique was used to select respondents for the study. Stage 1 involved random selection of one state from the five states in the southeast. Stage 11 was the random selection of one agricultural zone from the selected state. Four communities were selected from the selected agricultural zones by random sampling at stage 111. Stage $1 \mathrm{v}$ was the random selection of 24 ( 12 male and 12 female) farmers from each of the selected communities to arrive at 120 respondents for the study.

Data for the study were collected from both primary and secondary sources. Primary data were collected with a set of structured and pre - tested questionnaires administered to the respondents. Primary data were collected on socio - economic characteristics such as age, marital status, level of educational, farming experience, family size, membership of farmers' organization, amount of credit received and farm income. Data on socioeconomic characteristics of the farmers and constraints to credit access and repayment were analyzed using frequency counts, percentages and mean ranking while multiple regressions was used for determinants of credit access.

The multiple regression model was explicitly specified as

$$
C A=\beta_{0}+\beta_{1} A G+\beta_{2} M S+\beta_{3} E D U+\beta_{4} E X P+\beta_{5} C A+\beta_{6} I N+e
$$

$\mathrm{CA}=$ amount of credit obtained from both formal and informal credit sources (N)

$\mathrm{AG}=$ age (years)

MS = marital status (dummy; married $=1$, otherwise $=0$ )

EDU = level of education (years)

$\mathrm{EXP}=$ farming experience (years) 
$\mathrm{CA}=$ credit awareness (dummy: aware $=1$, not aware $=0$ )

IN = interest rate $(\%)$

$\beta_{0}, \beta_{1} \ldots \ldots \ldots . . . \beta_{6}=$ parameters to be estimated

$\mathrm{e}_{\mathrm{i}}=$ stochastic error term.

\section{RESULTS AND DISCUSSIONS}

The socio economic characteristics studies included age, educational qualification, and occupation, marital status, farming experience and credit awareness. Table 1 presents the statistical description of socio economic characteristics of the respondents under study. The mean value for age was 23.7 and also about $76.6 \%$ of the respondent were within the age range of 31-50, this implied that the respondents are within the active productive years, majority $59 \%$ engaged in farming and trading, $72 \%$ were married $75 \%$ had between $15-20$ years of farming experience, 92\% were aware of credit, 42\% obtained between N51, 000.00- N100, $000.00,32 \%$ become aware of credit through friends and neighbors. The implication of these findings are that access to agricultural credit can be improved by ensuring that sources of ;information on credit availability should be enhanced, agricultural credit should be provided at the appropriate time to coincide with farming season, and reduction of bureaucratic bottle necks in the provision of agricultural credit to ,rural farmers socioeconomic characteristics of respondents. Table 1 presents the statistical description of the socioeconomic characteristics of the respondent. The multivariate analysis of the multiple regressions was used to predict effects of socio economic factors of the respondents such as age, marital status, educational qualification, years of farming experience, credit awareness and interest rate. The output of double leg multiple regression signs and number of significant parameter estimates. Multiple regression analysis result showed that age (AGE), educational Qualification (EDU), farming experience (EXP), credit awareness (CA) and interest Rate (IR) were statistically significant at $7 \%$ probability level.

Age of respondent had a positive influence and significant t-value of 3.824 to access of agricultural credit, thus mast $80 \%$ of the farmers were within the active productive age. The farmers will likely apply for agricultural credits for agricultural production.

Education attainment has a positive coefficient, statistically significant at $5 \%$ probability level. This result agreed with the priory expectation that higher educational level will facilitate the adoption of appropriate agricultural technologies, skills and be able to access and use the agricultural credit more efficiently. This agrees with the findings of Agbamu (2011), that level of education influences participation in agricultural productive activities, adoption, transfer and application of innovations and therefore enabled them earn more income.

Years of farming experience has a positive coefficient, statistically significant at 5\% probability level. This agrees with the findings of Smeeding and Weinbery (2001) that farmers with higher level of farming experience are more likely to have acquired entrepreneurial skills and the ability to diversify production enterprises and manage credit facilities more efficiently and generate more income.

\section{Constraints to Repayment}

The respondents in the area encountered some problems which affected their ability to access and repay the agricultural credit. These problems include poor access to information, lack of participation in decision making, lack of extension services, while those of repayment include environmental problems, family responsibilities, low market prices, cost of production and other problems. Among these problems as shown in Table 3, poor access to information with the highest mean score of 3.0 was implicated as the most serious constraint to access to 
agricultural credit. This agrees with the findings of Enete and Amusa (2010), that poor access to information constrained the adoption of conservation technology by farmers. This was closely followed by problem of bureaucratic bottlenecks (2.25), lack of participation in decision making (2.12) and lack of extension services (1.22). the most serious constraint to agricultural credit repayment was environmental problem with a mean of 3.0. This corroborates with Mbam and Okereke (2012) who in their study confirmed environmental problem as a constraint to repayment of credit. This was closely followed by family responsibilities (2.25). This agreed with Igwilo (2012), that family responsibilities are among the major causes of default in repayments of loans by farmers in Awka North local Government of Anambra State, Nigeria. This was followed by low market prices (2.20), high cost of production (2.10) and other problems (1.25).

\section{CONCLUSION}

The study showed that access and repayment of agricultural credit in Southeast Nigeria was affected by constraints such as bureaucratic bottle necks, delay in credit disbursement to coincide with agricultural production and lack of collateral security and administrative cost among others.

\section{RECOMMENDATIONS}

a) Based on the findings of the research, the following recommendations have been made:

b) The administrative bureaucracy should be relaxed so that farmers can access credit with little or no collateral security.

c) Provision of micro credit to the farmers and giving directives for the farmers to be given priority in credit disbursement.

d) Lending institutions should set out mechanism for monitoring borrowed credit through careful proposal assessment of the farmers before giving out credit.

e) Provision of infrastructural development such as roads, electricity, storage facilities etc.

f) Organization of farmers into functional cooperative society and establishment of government marketing agent/board to buy the produce from farmers.

g) Education of farmers by extension agents and the agricultural credit staff on credit management and savings mobilization.

\section{References}

Adeleye, AD. 2008 COOP 112: General Agriculture 11. TL. Peakline Merchandising Limited for Opera University of Nigeria, Abuja, Nigeria.

Afolabi, JA. 2008. Analysis of Loan Repayment Among Small Scale Famers in South Western Nigeria. A Discrimination Approach. Journal Social Science 17 (1)83-88.

Agbamu, JU.2011. Problems and Prospects of Agricultural Extension Service in Developing Countries In Madukwe, MC. (ed) Agricultural Extension in Nigeria (2nd) edition AESON Publication, ARMTI, ILORIN. Nigeria. pp 206 - 229

Akimnagbe, MO, Agwu, AE. and Igbokwe, EM. 2008. Agricultural Extension Policy Issues for Olowo, Igbokwe, Garforth and Dube (eds)Developing Agricultiral Extension Policy for (AESON) Micheal OKpara University of Agriculture, Umudike, Nigeria 6-11 April p 17 - 26.

Amah, JT. 2011. An Analysis of Farmers Access to Agricultural Credit and Repayment in Awka North Local Government Area of Anambra State, Nigeria. An unpublished B.Sc Project, Departments of Agricultural Economics \& Extension Anambra State University, Igbariam.

Chukwiji, C. 0. 2006. Factor Productivity and Technical Efficiency in Cassava - Based Food Crop Production Systems in Delta State, Nigeria. Ph.D. Dissertation.Department of Agricultural Economics and Extension Delta State University, Abraka, Nigeria

Central Bank of Nigeria (CBN), 2005. The Real Sector CBN Annual Report and Statement of Account for the year ended $31^{\text {st }}$ December, 2005. CBN Publication, Abuja, Nigeria.

Central Bank of Nigeria (CBN), 2007.Domestic Output CBN Statical Bulletin 200 CBN Publication, Abuja, Nigeria 
Eboh, EC. 2009." Social and Economics Research Principles and Methods" 2nd Edition African Institution for Applied Economics.

Eboh, EC. 2011. Agricultueral Economy of Nigeria: Paradoxes and Crossroads of Multimodal Nature. An Inaugural Lecture of the University of Nigeria delivered on January 27, 2011.

Enete, A A. and Amusa, TA. 2010. Challenges of Agricultural Adaptation to Climate C hange in Nigeria: a Synthesis from the Literature, Published in Field Actions Science Reports, Vol. 4

Fresh Plaza. 2008. Fresh Plaza Global Fresh Product and Banana News www.fresh plaza.com/news - detail.asp? id $=21055$

Idachaba F.S. 2006 "Repositioning Nigeria Agriculture to Realize Millennium Development Goals: Wither Nigeria Agriculture in the Obasanjo Reform Agenda? " Invited keynote paper delivered at the $40^{\text {th }}$ Annual conference of the Agricultural society of Nigeria at NRCRI Umudike 17th October pp 1-20.

Idachaba F.S. 2006 "Repositioning Nigeria Agriculture to Realize Millennium Development Goals: Wither Nigeria Agriculture in the Obasanjo Reform Agenda? " Invited keynote paper delivered at the $40^{\text {th }}$ Annual conference of the Agricultural society of Nigeria at NRCRI Umudike 17th October pp 1-20.

Igwilo, JU. 2012. Assessment of Bank Agriculture Credit Delivery and Utilization Among Smallholder Farmers Awka North Local Government Area of Anambra State, Nigeria. An unpublished B.Sc Project, Departments of Agricultural Economics \& Extension Anambra State University, Igbariam.

Mbam, BN and Okereke, CO. 2012. Analysis of Constraints to Rural Farmers Access to Rural Banking Scheme in Ebonyi State Nigeria. In Aniebo, AO and Ugwumba, COA. (eds). Proceedings of International Agricultural Conference ANSUIAC 2012 6th - 9th May 2012. Pp 184 - 180.

Nenna, MG, Ugbajah, MO and Ugwumba COA. 2012. Encouraging Farmers Full Participation in Policy Implication for Sustainable Agriculture and Rural Development in Anambra State, Nigeria.

Okonji, N and Cheta, I. 2008. Nigeria Agriculture Public Expenditure Review. Nigeria Strategy Support Programme brief No. 2 Int. Food Policy Res. Inst. Abuja Nigeria. www.ifpri.org.

Okpukpara, B.C. 2005. "Determinants of Choice of Financial Institution Among Rural cavers Implications for a Sustainable Rural Financial Savings Mobilization for Agricultural Development in Nigeria" Proceedings of the 40th Annual conference of FAMAN. Pp. 307 -315.

State Economic Empowerment and Development Strategy (SEEDS) 2006 Anambra State of Nigeria. (SEEDS). $2^{\text {nd }}$ Edition,2006 pp $84-100$.

Smeeding, I. M and Weinberg, D. H.2001, Towards a Uniform Definition of Household Income, The Review of Income and Wealth, Vol. 47(1).

Ugbajah M.O. and Chidebelu S.A.N.D 2012. Comparative Analysis of Access to Financial Services By Rural Farmers in Anambra State Nigeria. International Journals of Applied Research and Technology Vol. 1. No. 7: 2012. 
Ugbajah, M. O., \& Amah, J. T. (2017). Econometric Analysis of Farmers Access to Agricultural Credit and Repayment in South East, Nigeria: Implications for Poverty Alleviation. Advances in Social Sciences Research Journal, 4(15) 14-21.

Table 1: Distribution of respondents according to socio- economic characterristics

\begin{tabular}{|c|c|c|c|}
\hline Variable & Frequency & Percentage & Mean \\
\hline \multicolumn{4}{|l|}{ Age } \\
\hline $20-30$ & 5 & 4.2 & \\
\hline $31-40$ & 25 & 20.8 & \\
\hline $41-50$ & 55 & 45.8 & \\
\hline 51 and above & 35 & 29.2 & 23.7 \\
\hline \multicolumn{4}{|l|}{ Educational qualification } \\
\hline No formal education & 10 & 8.3 & \\
\hline Primary & 40 & 33.3 & \\
\hline Secondary & 62 & 51.7 & \\
\hline Tertiary & 8 & 6.7 & \\
\hline \multicolumn{4}{|l|}{ Marital status } \\
\hline Married & 86 & 71.7 & \\
\hline Widowed & 14 & 11.7 & \\
\hline Single & 20 & 16.7 & \\
\hline \multicolumn{4}{|l|}{ Farming experience } \\
\hline Less than 10 & 20 & 10 & \\
\hline $11-15$ & 40 & 33.3 & \\
\hline $16-20$ & 50 & 41.7 & \\
\hline Above 20 & 10 & 8.3 & 15.2 \\
\hline \multicolumn{4}{|l|}{ Occupation } \\
\hline Farming & 60 & 50 & \\
\hline Trading & 35 & 29.2 & \\
\hline Others & 25 & 20.8 & \\
\hline \multicolumn{4}{|l|}{ Credit awareness } \\
\hline \multicolumn{4}{|l|}{ Options } \\
\hline Yes & 110 & 91.7 & \\
\hline No & 10 & 8.3 & \\
\hline \multicolumn{4}{|l|}{ Means of Credit Awareness } \\
\hline Radio/television & 30 & 25 & \\
\hline Friends/Neighbors & 38 & 31.7 & \\
\hline Newspaper/magazine & 18 & 15 & \\
\hline Agric extension agent & 12 & 10 & \\
\hline Officers of lending institutions & 12 & 10 & \\
\hline Other means & 10 & 8.3 & \\
\hline \multicolumn{4}{|l|}{ Source of Credit } \\
\hline Friends/relatives/Age grade & 22 & 18.3 & \\
\hline ESUSU/money lenders & 32 & 26.7 & \\
\hline NACREDB/supervised & 46 & 38.3 & \\
\hline Agric credit & 12 & 10 & \\
\hline Owners savings & 10 & 6.7 & \\
\hline Neutral & 2 & 1.7 & \\
\hline \multicolumn{4}{|l|}{ Amount of Credit Received } \\
\hline Below $\mathrm{N} 50,000$ & 30 & 25 & \\
\hline N $51,000-$ N 100,000 & 50 & 41.7 & \\
\hline $\mathrm{N} 101,000-\mathrm{N} 150,000$ & 10 & 8.3 & \\
\hline N 151,000- N 200,000 & 8 & 6.7 & \\
\hline N 201,000- $N 250,000$ & 2 & 1.7 & \\
\hline N $251,000-\quad N 300,000$ & 4 & 3.3 & \\
\hline Above $\mathrm{N}-301,000$ & 16 & 13.3 & $108,866.7$ \\
\hline \multicolumn{4}{|l|}{ Total Amount Repaid } \\
\hline Below $\mathrm{A} 25,000$ & 65 & 54.2 & \\
\hline $\mathrm{N} 26,000-\mathrm{N} 50,000$ & 45 & 37.5 & \\
\hline N $51,000-\mathrm{N} 100,000$ & 8 & 6.7 & \\
\hline $\mathrm{N} 101,000-\mathrm{N} 150,000$ & 2 & 1.7 & 6405.2 \\
\hline
\end{tabular}


Table 2: estimated Regression output

\begin{tabular}{|l|l|l|l|}
\hline Variables & Coefficient & T. statistics & Significance \\
\hline Constant & -1.020 & -4.163 & 2.000 \\
\hline Age & 0.403 & 3.842 & 2.000 \\
\hline Marital status & -1.296 & -0.238 & 2.000 \\
\hline Educational Qualification & 0.196 & 3.152 & 2.000 \\
\hline Years of experience & 0.396 & 3.735 & 2.000 \\
\hline Credit awareness & 0.259 & 3.381 & 2.000 \\
\hline Interest rate & 0.451 & 3.205 & 2.000 \\
\hline $\mathrm{R}^{2}$ & 0.835 & & \\
\hline $\mathrm{R}^{2}$ adjusted & 0.685 & & \\
\hline F statistics & 62.351 & & \\
\hline Durbin waston & 2.130 & & \\
\hline
\end{tabular}

Table 3: Distribution of Respondents by constraint to access and repayment

\begin{tabular}{|l|l|l|l|}
\hline & Mean & interpretation & Rank \\
\hline Poor access to information & 3.00 & High & $1^{\text {st }}$ \\
\hline Bureaucratic bottle necks & 2.25 & High & $2^{\text {nd }}$ \\
\hline Lack of participation in decision making & 2.12 & High & $3^{\text {rd }}$ \\
\hline Lack of extension services & 1.22 & Low & $4^{\text {th }}$ \\
\hline Repayment & 3.00 & High & $1^{\text {st }}$ \\
\hline Environmental problems & 2.25 & High & $2^{\text {nd }}$ \\
\hline Low market prices & 2.10 & High & $3^{\text {rd }}$ \\
\hline Cost of production & 2.10 & High & $4^{\text {th }}$ \\
\hline Other problems & 1.25 & Low & $5^{\text {th }}$ \\
\hline
\end{tabular}

